\title{
YIELD LOSSES DUE TO INBREEDING AND THE USE OF MOLECULAR MARKERS (RAPD) FOR ASSESSMENT OF GENETIC PURITY IN HYBRID CORN (Zea Mays L.)
}

\author{
CLAUDINEI ANDREOLI ${ }^{1}$, CÉSAR C. CARVALHO ${ }^{2}$, RAMIRO V. DE ANDRADE $^{3}$ \\ ${ }^{1}$ Embrapa Soja, Caixa Postal 231, 86001-970, Londrina, PR., Brazil, e-mail: andreoli@ cnpso.embrapa.br (corresponding \\ author) \\ ${ }^{2}$ Fellowship, North Dakota State University, Fargo, ND, USA \\ ${ }^{3}$ Embrapa Milho e Sorgo, Caixa Postal 151, 35.700-970, Sete Lagoas, MG, Brazil, email: ramiro@cnpms.embrapa.br
}

Revista Brasileira de Milho e Sorgo, v.5, n.1, p.1-14, 2006

\begin{abstract}
The production of hybrid corn (Zea mays L.) requires the complete removal of pollen of the female parent prior to pollination. The objectives of this study were to evaluate the percentage of female selfed plants that results in losses due to inbreeding and to assess the usefulness of RAPD approach in monitoring genetic purity of three kinds of commercial hybrid maize. Contamination levels of $0 \%, 1 \%, 2 \%, 3 \%, 4 \%, 5 \%$, $6 \%, 8 \%$ and $10 \%$ in the female parent HS for seed production of hybrids BRS 201 and BRS 205 were used. In another trial, contamination levels of $0 \%, 1 \%, 3 \%, 5 \%, 8 \%$ and $10 \%$ were used in the BRS 3123 hybrid seeds. Contamination level was monitored leaving female plants without detasseling in the hybrid production field. Determination of cob appearance, kernel colour, grain and ear yield of these hybrids were carried out in the field, at maturity. DNA from $\mathrm{F}_{1}$-hybrids and their parents was employed to RAPD screening with 80 primers. The product was 456 bands, being 8 bands polymorphic. Field comparisons at maturity were generally more accurate at low levels of contamination. Yield losses increased with admixture levels; and it was up 27\% for BRS 201, $8 \%$ for BRS 205 and 25\% for BRS 3123. The primers, OPN-04 and OPR-19, were able to discriminate the contaminants among the pure seed hybrids and their parents. The RAPD procedure was able to detect polymorphism and contaminants in the seed lots, up to $3 \%$. The results of this work indicate the practical usefulness of RAPD markers in monitoring purity tests and inbreed lines identification of commercial maize hybrids. Other advantages of the DNA approach included speed and the ability to determine the percentage of female self prior to harvest.
\end{abstract}

Key words: DNA, contaminant, pollination, hybrid production, heterosis.

\section{PERDAS NO RENDIMENTO DEVIDO À ENDOGAMIA E USO DE (RAPD) PARA MONITORAR A PUREZA GENÉTICA EM HÍBRIDOS COMERCIAIS DE MILHO (Zea Mays L.)}

RESUMO - A produção de sementes híbridas de milho exige a erradicação completa do pendão floral do parental fêmea, antes da antese. Os objetivos deste trabalho foram: 1- 
determinar os níveis de contaminação genética dos híbridos duplos BRS 201 e BRS 205 e triplo BRS 3123 que resultam na queda de produtividade; 2 - verificar os marcadores moleculares (RAPD) que identificam os contaminantes; 3 - monitorar a pureza genética na produção comercial de milho híbrido. Os níveis de contaminação de pólen, usados na produção dos híbridos BRS 201 e BRS 205 foram: 0\%, 1\%, 2\%, 3\%, 4\%, 5\%, 6\%, 8\% e $10 \%$ de plantas não despendoadas no parental feminino. Em outro ensaio, contaminações de $0,1 \%, 3 \%, 5 \%, 8 \%$ e $10 \%$ foram usadas no híbrido triplo BRS 3123 . Determinações da aparência da espiga, cor de grão e produção de grãos e espigas foram feitas no campo, na maturidade. Os DNAs das sementes dos híbridos e dos parentais foram extraídos das plântulas e o produto de 456 bandas foi obtido, sendo oito polimórficas. As comparações de campo, na maturidade, foram geralmente mais acuradas, com níveis baixos de contaminantes. A redução da produtividade de grãos foi de $27 \%$ para o BRS 201, de $8 \%$ para o BRS 205 e de $25 \%$ para o BRS 3123. Os marcadores OPN-04 e POR19 foram capazes de discriminar as variações entre a semente pura (híbridas) e seus parentais. A técnica de RAPD foi capaz de detectar polimorfismo e contaminantes nos lotes de sementes, até o nível de 3\%. Os resultados deste trabalho indicaram que a técnica de RAPD é uma ferramenta útil para monitorar pureza genética na produção de híbridos de milho. Outra vantagem dessa técnica inclui a rapidez e a habilidade de determinar a porcentagem de mistura, antes da colheita.

Palavras-chave: DNA, contaminante, polinazação, produção de híbido, heterose.

Corn is one of the major crop productions in Brazil and the production was 42,345.6 tons in 2003/04, which represented $37.8 \%$ of the total grain production (Conab, 2004; www.conab.gov.br).

The production of hybrid seed corn requires the complete elimination of pollen produced by female parent. Incomplete removal of the male flower from the female parent provides the potential for self-pollination to occur. The resultant selfed seeds will contaminate seed lots reducing genetic purity, revealed in the field as less vigorous and possible barren plants, thereby, resulting in reduced yield (Andreoli et al., 1996; Pinho et al., 1996). Thus, it will reduce the genetic gains obtained by heterosis (Duvick, 1977; 1992; Meghji et al., 1984).

Determination of the genetic purity of lines and $\mathrm{F}_{1}$-hybrid seeds is a quality control requirement of critical importance for plant breeding and seed production. One approach to checking hybrid seed lots for purity is the growout that under field conditions quantifies the frequency of contaminants, e.g., female self. An alternative method for detecting contamination from female self uses electrophoretic isozymes pattern from seedlings through lack of bands donated from male parent (Smith \& Smith, 1992; Smith \& Weissinger, 1984). Techniques based on the polymerase chain reaction (PCR) have been proposed to detect polymorphisms in plants (Welsh \& McClelland, 1990; Williams et al., 1990; Caetano-Anolles et al., 1991), and to assess genetic purity of seed lots in maize (Welsh et al., 1991), in tomato (Hashizume et al ., 1993; Rom, et al ., 1995), and in watermelon (Hashizume et al ., 1993). The randomly amplified polymorphic DNA technique (RAPD) is relatively fast and 
simple to operate, requires small amount of DNA, and it does not require the use of radioactive material. The polymorphisms may be used as dominant genetic markers.

The objectives of the present work were to evaluate yield losses due to inbreeding and to employ RAPD approach in monitoring genetic purity of inbred lines and commercial hybrid corn seeds.

\section{Material and Methods}

\section{Yield loss due to genetic mixture}

In this experiment inbred lines L20, L16, L1154, two double cross hybrids (BRS 201 and BRS 205) and one triple hybrid BRS 3123 were used. These materials were kindly supplied by Embrapa. The inbreed lines were maintained as pure stocks and ears were harvested individually. For the hybrids, BRS 201 and BRS 205, the seed lots were constructed with contamination levels of $0 \%, 1 \%, 2 \%, 3 \%, 4 \%, 5 \%, 6 \%, 8 \%$ and $10 \%$ by leaving the female plants spreading pollen out in the plot, and for the triple hybrid the contamination levels of $0 \%, 1 \%, 2 \%, 3 \%, 5 \%$, $8 \%$ and $10 \%$ were used. To obtain these contamination levels, four rows of 100 female parent plants were grown in isolated fields adjacent to two rows of male. At the time of pollination, the female plants were detasseled correspondent to the mixture level (e.g.: $0 \%$ of mixture means all plants were detasseled; $1 \%$ of mixture means that one female plant, in 99 plants, was not detasseled, and so on...). All plots were protected from out-cross pollen by a border of 10 row-female plants.

At harvest, 20 cobs of each plot were hand threshed and a sample of 400 kernels was mixed and subdivided into two samples of 200 kernels. One of these, a 200-kernel sample of each contamination level for each hybrid, was evaluated for percentage of self by RAPD analysis. The second 200-kernel sample was stored in a cold storage $\left(5^{\circ} \mathrm{C}\right.$ and $\left.30 \% \mathrm{RH}\right)$ at Embrapa Milho e Sorgo, Sete Lagoas, MG until yield evaluations. In November, kernels from each plot were planted in four rows of $5 \mathrm{~m}$, spaced of $0.90 \mathrm{~m}$, using a plant density of 55.550 plants per ha. All plots were hand-harvested, husked and individually threshed. The ear and grain yield and percentage moisture were recorded. The ear and grain yields were converted into kilogram per hectare at $13 \%$ moisture basis. Off-type self was identified at maturity by small ear size, ear shape and cob and kernel colour. A random block design with five replications was used in all trials. Inbreeding depression $\left(\mathrm{F}_{1}-\mathrm{F}_{2}\right)$ in actual units and percentage inbreeding depression $\left[100\left(1-\mathrm{F}_{2} / \mathrm{F}_{1}\right)\right]$ were calculated for yield. Yield loss was calculated taken 0 (zero)\% contamination as the basis of 100. To estimate the discrepancy between observed and actual levels of selfs, the value of $(\mathrm{Obs}-\mathrm{Exp})^{2}$ was recorded. This statistic was used to compare the accuracy of detecting self in the double cross hybrid BRS 201.

\section{RAPD assessment for genetic seed quality}

Seeds were germinated in rolls of watermoistened paper towels at $20 / 30{ }^{\circ} \mathrm{C}$. DNA extractions from 5-day-old seedlings were performed according to the method of Doyle \& Doyle (1990). For parental lines and $F_{1}$ hybrid, the DNA extracted from leaves from one hundred seedlings was pooled. After extraction, the concentration of DNA was determined and their samples were diluted to $10 \mathrm{ng} / \mathrm{mL}$.

Twenty- five microliters of PCR reactions were prepared by using 1 x Taq polymerase buffer 
adjusted to $10 \mathrm{mM}$ Tris- $\mathrm{HCl} 1$ (pH 8.6), $50 \mathrm{mM}$ $\mathrm{KCl}, 2 \mathrm{mM} \mathrm{MgCl}, 0,1 \mathrm{mM}$ of each dNTP, 0,16 $\mathrm{mM}$ primer, $1 \mathrm{U}$ Taq plymerase (Perkins-ElmerCetusâ, Norwalk, USA) and 25 ng template DNA. The reactions were overlaid with mineral oil and amplifications were carried out in a Thermocycler Perkin-Elmer-Cetusâ model 9600. The amplification temperature program for 40 cycles as: $94{ }^{\circ} \mathrm{C}$ for $15 \mathrm{sec}, 35^{\circ} \mathrm{C}$ for $30 \mathrm{sec}$, and $72{ }^{\circ} \mathrm{C}$ for $2 \mathrm{~min}$, followed by a stage of final extension of $72{ }^{\circ} \mathrm{C}$ for 7 minutes. After that, the temperature was lowered to $4{ }^{\circ} \mathrm{C}$.

At the end this reaction, $5 \mathrm{ml}$ of the PCR products were loaded onto a $1,4 \%$ agarose, the electrophoresis was run for 2 hours at 100 volts and the gels were stained with $1 \mathrm{mg} / \mathrm{ml}$ ethidium bromide in water. They were photographed under
UV light with EAGLE EYE (Stratagene Systems $^{\circledR}$, La Jolla/CA).

A total of 80 primers were used for RAPD screening of the single hybrid HS, BRS 201 and theirs parentals. These primers were acquired from OPERON ${ }^{\circledR}$ (Operon Technologies Inc. Alameda, CA) consisting of 4 kits of 20 primers: OPL 1-20; OPJ 1-20; OPN 1-20 and OPO 1-20.

\section{Results and Discussion}

The Table 1 presents the inbreeding depression means of contamination level for each hybrid from trials at Sete Lagoas, State of Minas Gerais, in 1999. The three hybrids used the same female parent for $F_{1}$ seed production. Analysis of variance results for

TABLE 1. Inbreeding depression means of the three hybrids for ear and grain yield, grown in Sete Lagoas, MG, in 1999.

\begin{tabular}{cllllll}
\hline & \multicolumn{7}{c}{ Hybrids } \\
\cline { 2 - 7 } Self Mixtures & \multicolumn{2}{c}{ BRS 201 } & \multicolumn{3}{c}{ BRS 205 } & \multicolumn{3}{c}{ B123 } \\
\cline { 2 - 7 }$(\mathbf{\%})$ & Ear & Grain & Ear & Grain & Ear & Grain \\
\hline 0 & $\mathbf{k g} / \mathbf{h a}$ & $\mathbf{k g} / \mathbf{h a}$ & $\mathbf{k g} / \mathbf{h a}$ & $\mathbf{k g} / \mathbf{h a}$ & $\mathbf{k g} / \mathbf{h a}$ & $\mathbf{k g} / \mathbf{h a}$ \\
\hline 1 & 0.0 & 0.0 & 0.0 & 0.0 & 0.0 & 0.0 \\
2 & -1222.0 & -1111.0 & +266.6 & +533.3 & -1137.8 & -980.0 \\
3 & -1111.0 & -1111.0 & -144.5 & -177.8 & -490.0 & -442.2 \\
4 & -2278.0 & -2056.0 & +844.5 & +744.5 & -385.6 & -341.1 \\
5 & -1167.0 & -1000.0 & +277.8 & +255.6 & -- & -- \\
6 & -2389.0 & -2111.0 & -288.9 & -288.9 & -632.2 & -178.9 \\
8 & -2389.0 & -2056.0 & -111.1 & -55.5 & -- & -- \\
10 & -2945.0 & -2556.0 & -803.6 & -522.9 & -304.4 & -261.1 \\
\hline Média & -2389.0 & -2111.0 & +166.7 & +166.7 & -1826.7 & -1585.6 \\
\hline LSD (5\%) & -1765.5 & -1568.0 & +322.6 & +305.0 & -682.4 & -541.3 \\
\hline
\end{tabular}


inbreeding depression in $\mathrm{kg} \mathrm{ha}^{-1}$ and percent inbreeding depression due to genetic mixtures inbreeding depression were the same for ear had a negative effect on ear and grain yield and grain yield (data not shown). The for the hybrid BRS 201, BRS 205 (Figure 1)
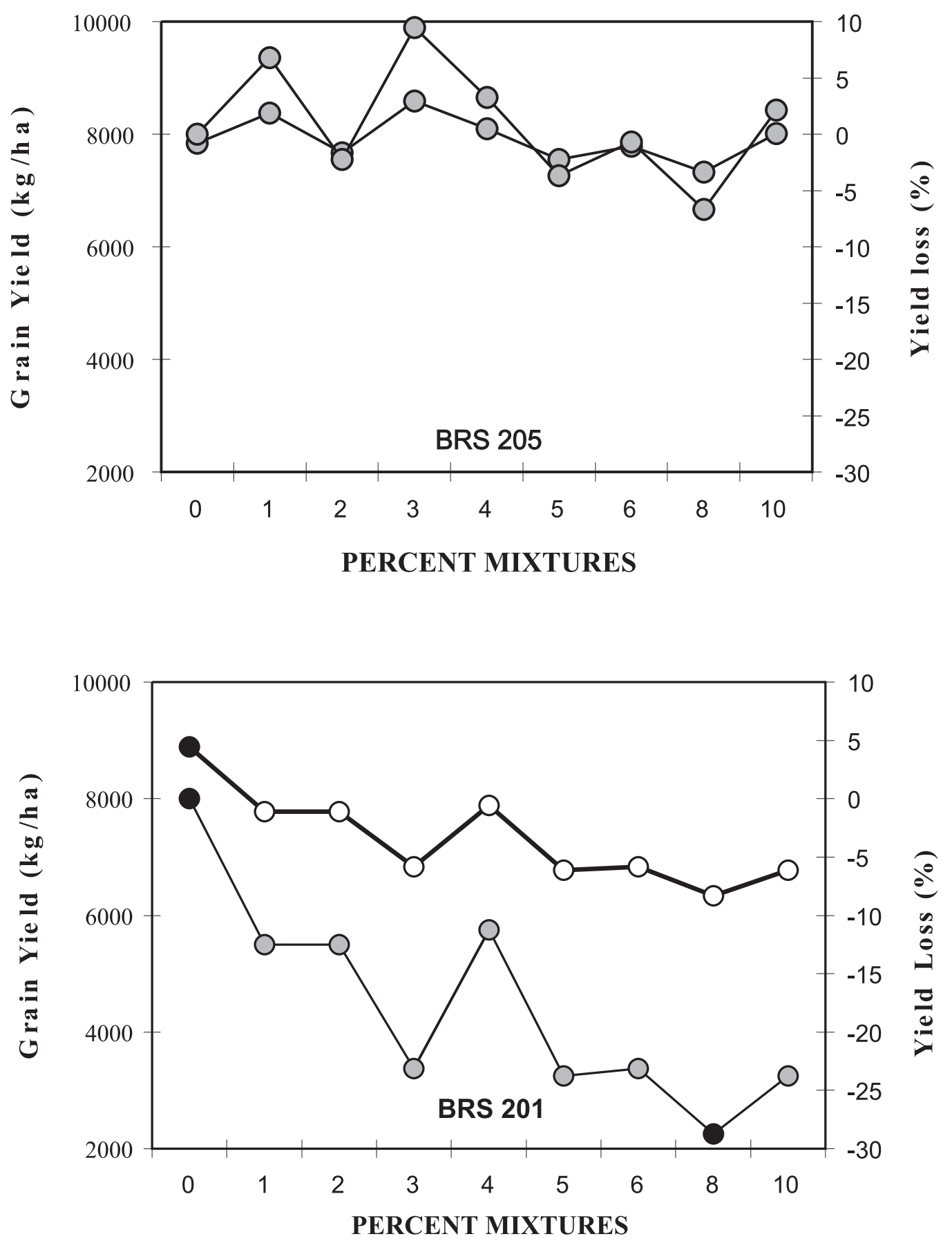

FIGURE 1. Mean yield (- - ) and inbreeding depression (-O - $\left(\mathrm{F}_{1}-\%\right.$ self in $\left.\mathrm{F}_{2}\right)$, due to percent genetic mixtures of selfing, in double hybrid maize BRS 201 and BRS 205 at Sete Lagoas, MG, in 1999. 
and BRS 3123 (Figure 2). The yield loss reached $27 \%$ for BRS 201 with $8 \%$ contamination level and yield was $8 \%$ less for BRS 205 with $8 \%$ of selfs. For BRS 3123, there was a substantial

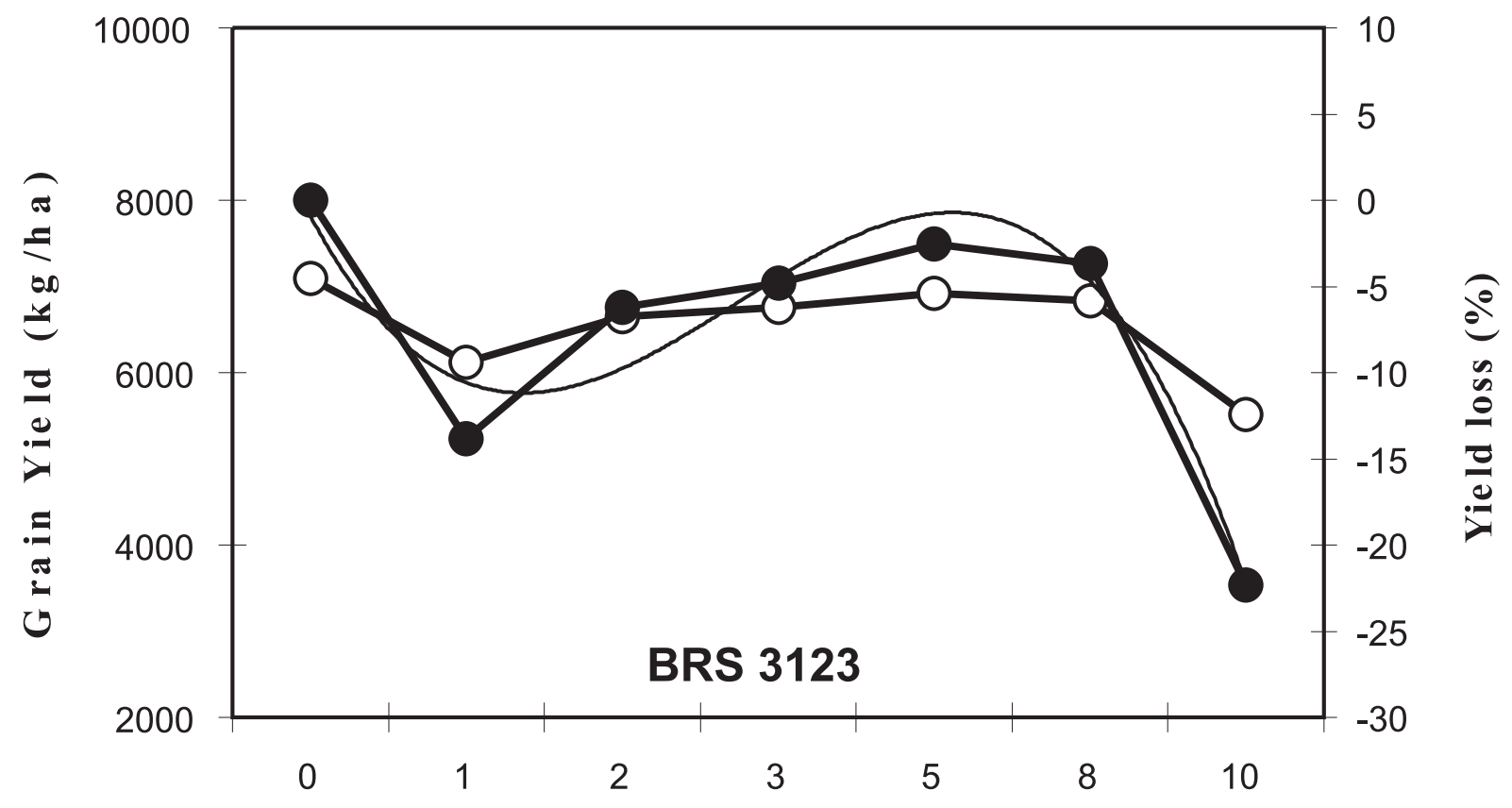

PERCENT MIXTURES

FIGURE 2. Mean yield (- - ) and inbreeding depression (-O - $\left(\mathrm{F}_{1}-\%\right.$ self in $\left.\mathrm{F}_{2}\right)$, due to percent genetic mixtures, in triple hybrid maize BRS 3123 at Sete Lagoas, MG, in 1999.

yield reduction at $1 \%$ of selfing and at $10 \%$, reduction of $25 \%$ was achieved. In addition, $\mathrm{Pi}-$ nho et al. (1996) estimated a $0,5 \%$ reduction on grain yield for each $1 \%$ of seeds derived from selfing mixed within hybrid seeds. The selfing plants produced in the $\mathrm{F}_{1}$ hybrid plots resulted in contaminants with large difference in cob size and shape, kernel color and shape (Figure 6), that contributed to yield loss in all hybrids.

A plausible explanation might be that the period of pollen shed and silking of the hybrid BRS 201 was more disperse. Therefore, a certain amount of non-detasselled parent female plants would result in greater amount of sibling and selfed seeds in the seed lot, which resulted in yield losses in $\mathrm{F}_{2} \mathrm{~s}$.

Table 2 presents the percentages of offtype female selfs observed and expected from field trial for the hybrid BRS 201, at maturity. The statistic for all observations are presented in Table 3, where large values of (Obs-Exp) ${ }^{2}$ indicated great discrepancy between observed and actual levels of selfs. Scoring ear appearance at maturity of 0-4\% levels was clearly more accurate than higher levels of selfs. Scoring ear piles at maturity was clearly more accurate than at earlier growth stages. The hybrid BRS 3123 was the least accurately rated using ear characters. 


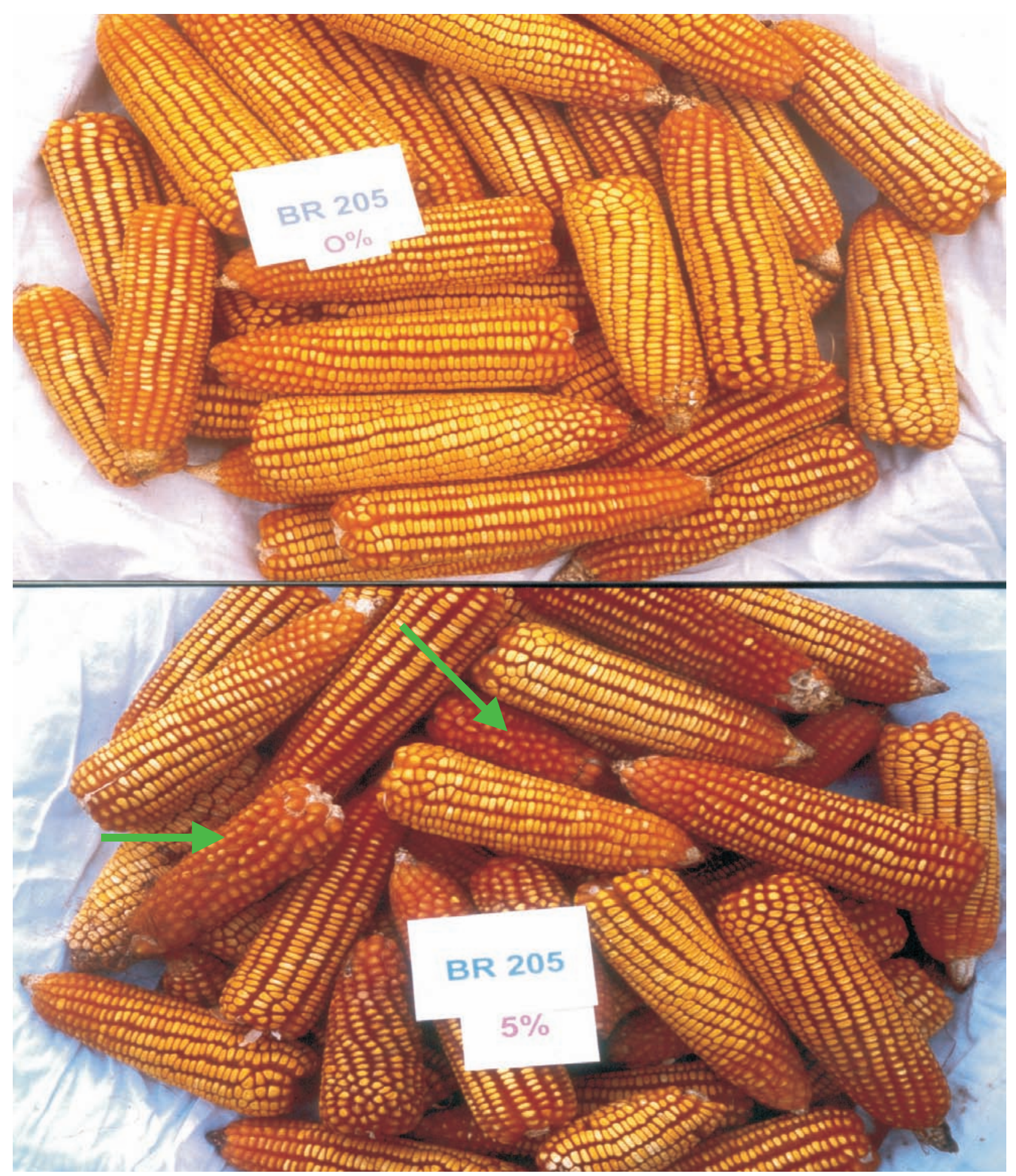

FIGURE 6. Illustration of genetic mixture of 5\% selfing in comparison to pure seed (0\%) during hybrid corn production of BRS 201at Sete Lagoas, MG in 1999. The yield fell off $8 \%$. The arrows show the contaminant cobs with differences in size, kernel shape and color. 
TABLE 2. Percentages of female selfs observed and expected from field trial for the hybrid BRS 201, at maturity.

\begin{tabular}{cccc}
\hline Observed & Expected & Obs-Exp & (Obs-Exp) $^{2}$ \\
\hline 0.2 & 0 & 0.2 & 0.04 \\
1.4 & 1 & 0.4 & 0.16 \\
2.2 & 2 & 0.2 & 0.04 \\
1.2 & 3 & -1.8 & 3.24 \\
3.4 & 4 & -0.6 & 0.36 \\
1.6 & 5 & -3.4 & 11.56 \\
2.8 & 6 & -3.2 & 10.24 \\
3.4 & 8 & -4.6 & 21.16 \\
\hline 5.4 & 10 & -4.6 & 21.16 \\
\hline Total & $\sum(\text { Obs-Exp })^{2}=$ & & 67.96
\end{tabular}

The square root of the average across hybrids of $(\mathrm{Obs}-\mathrm{Exp})^{2}$ presents the mean deviation of observed from actual contamination levels at maturity. Smith \& Wych (1986), testing electrophoretic and morphological traits to estimate the percentage of female selfed plants, observed similar results in seed lots of four maize hybrids.

\section{RAPD Analysis}

The 80 primers tested amplified approximately 456 products, ranging from 0.7 to $2.8 \mathrm{kbp}$. Eight out of a total of $456 \mathrm{PCR}$ products observed were polymorphic between the parents. Of the 80 primers screened, eight reproducibly amplified RAPD's each allowed the distinction of at least one hybrid from its

TABLE 3. Example of calculation used to compare the accuracy of different levels of contaminations for the three hybrids.

\begin{tabular}{cccc}
\hline $\begin{array}{c}\text { Hybrid } \\
(\text { Obs-Exp) }\end{array}$ & $\mathbf{0 - 4 \%}$ selfs & $\mathbf{5 - 1 0 \%}$ selfs & $\mathbf{0 - 1 0 \%}$ selfs \\
\hline BRS 201 & 3.84 & 64.12 & 67.96 \\
BRS 205 & 4.40 & 63.12 & 67.52 \\
BSR 3123 & 9.40 & 59.56 & 68.96 \\
\hline$\sqrt{\text { Means }}$ & 4.22 & 13.67 & 14.30 \\
\hline
\end{tabular}

parent (Table 4). A paternal-specific RAPD marker for these eight primers and their expected dominant inheritance patterns were reproduced in the single hybrid HS 200 (Figure 3).
Figure 3 showed us that the primer OPL04 produced a unique fragment of $900 \mathrm{bp}$ in the male parent line and in the $\mathrm{F}_{1}$ (HS 200). The product was reproducible and the female parent 
TABLE 4. Primers used for the parents and $\mathrm{F}_{1}$ HS 200 (see Figure 3).

\begin{tabular}{ccccc}
\hline Primer & Sequence & $\begin{array}{c}\text { Total } \\
\text { Product }\end{array}$ & $\begin{array}{c}\text { Polymorphic } \\
\text { Band }\end{array}$ & $\begin{array}{c}\text { MW } \\
\text { Polymorphic }\end{array}$ \\
\hline OPG-12 & 5'-CAGCTCACGA-3' & 06 & 02 & $1, .200 ; 900$ \\
OPH-19 & 5'-CTGACCAGCC-3' & 05 & 01 & 1.300 \\
OPL-04 & 5'-GACTGCACAC-3' & 05 & 01 & 900 \\
OPR-11 & 5'-GTAGCCGTCT-3' & 06 & 01 & 1.300 \\
OPY-07 & 5'-AGAGCCGTCA-3' & 05 & 01 & 1.400 \\
OPX-17 & 5'-GACACGGACC-3' & 05 & 01 & 1.450 \\
OPR-19 & 5'-CCTCCTCATC-3' & 05 & 01 & 2.000 \\
OPX-19 & 5'-TGGCAAGGCC-3' & 06 & 01 & 1.700 \\
\hline
\end{tabular}

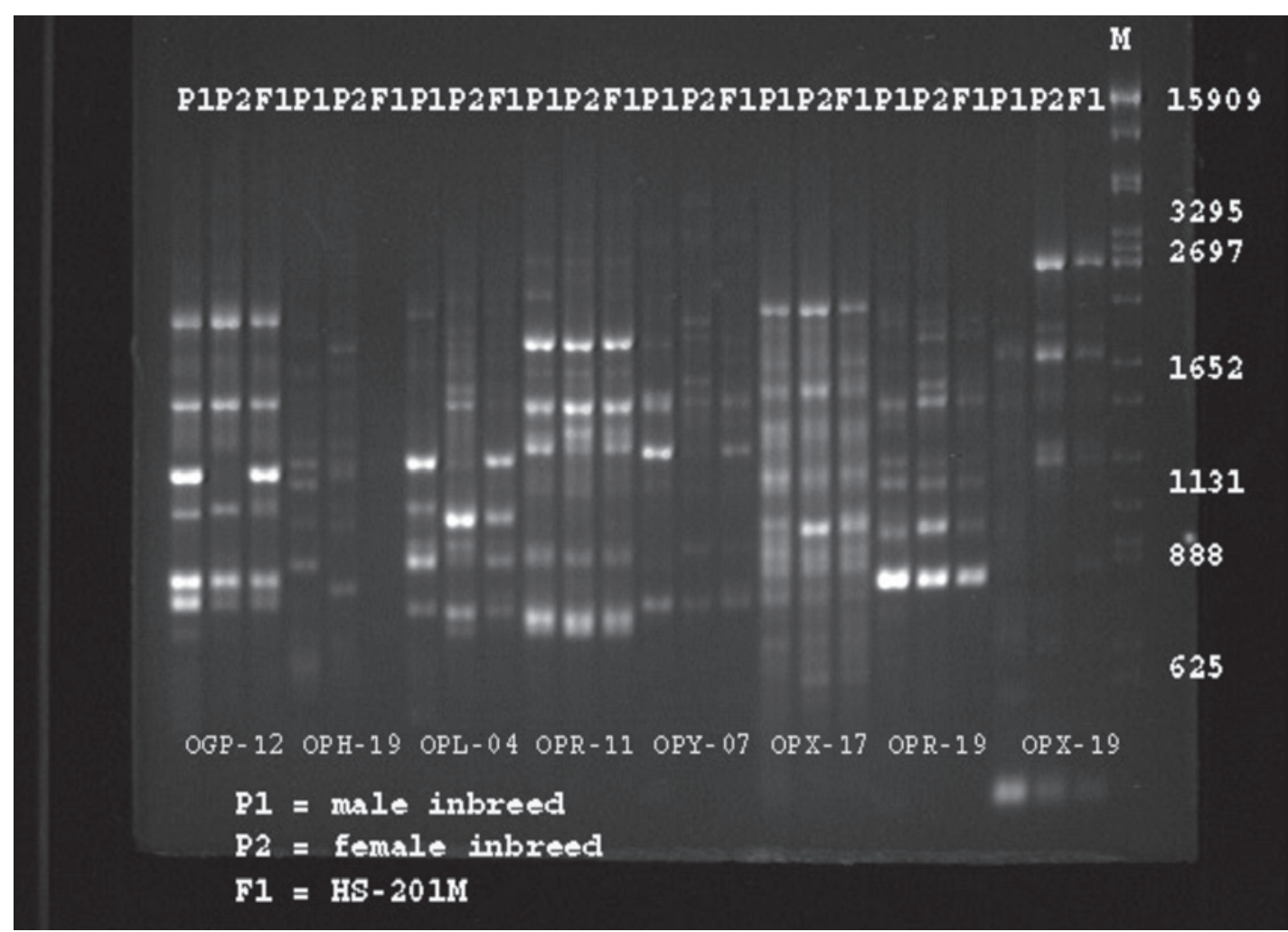

FIGURE 3. Agarose-gel electrophoresis of randomly amplified genomic DNA products from HS 200 and their corresponding inbred parents. The RAPD products shown were generated by the oligonucleotide primers OPG-12, OPH-19, OPL-04, OPR-11, OPY-07, OPX-17, OPR-19, OPX-19. Lanes represent EcoRI, HindIII and BamHI digested l-DNA size markers. 
could be discriminated from the $F_{1}$ using this fragment as a molecular marker.

In another study, 80 primers were used to screen RAPD of the double hybrid BRS201 and theirs parents. Of the 80 selected, five produced fragments that made it possible to distinguish the hybrid from either female parent or self- $\mathrm{F}_{2}$ plants

(Table 5). Of the 80 primers tested, five generated

TABLE 5. 1 Primers used for the parental lines and BRS 201 (see Figure 4).

\begin{tabular}{ccccc}
\hline \multirow{2}{*}{ Primers } & Sequence & $\begin{array}{c}\text { Total } \\
\text { Product }\end{array}$ & $\begin{array}{c}\text { Polymorphic } \\
\text { Band }\end{array}$ & $\begin{array}{c}\text { MW Polymorphic } \\
\text { (bp) }\end{array}$ \\
\hline OPG-12 & 5'-CAGCTCACGA-3' & 09 & 01 & 1.300 \\
OPL-04 & 5'-GACTGCACAC-3' & 08 & 01 & 1.400 \\
OPJ-16 & 5'-CTGCTTAGGG-3' & 06 & 01 & 1.200 \\
OPO-09 & 5' -TCCCACGCAA-3' & 06 & 01 & 2.000 \\
OPN-04 & 5'-GACCGACCCA-3' & 07 & 01 & 1.600 \\
\hline
\end{tabular}

fragments allowed discriminating the $F_{1}$ from theirs parents, and just one generated polymorphism with a band present in the $\mathrm{P}_{1}$ and absent in the $\mathrm{P}_{2}$ (Figure 4).

The low occurrence of polymorphism DNA products (5 out 480 ) reflects a status of relatively low genetic variability, suggesting that the inbred lines are closely related to each other. In these cases, the morphological determination of the genetic purity of the hybrid seeds is rather difficult. The primer OPN-04, produced a single marker of $1,600 \mathrm{bp}$ present in $\mathrm{P}_{1}$ and $\mathrm{F}_{1}$ and absent in the $\mathrm{P}_{2}$, demonstrating its dominance inheritance pattern in the hybrid BRS 201 This fragment disappeared as the contamination levels increased up to $3 \%$, although it is far from the standard tolerance of $1 \%$ for hybrid seed production (Figure 5).

The combination of simplicity of the RAPD and efficient DNA-extraction protocols from seedlings (Norm Weeden, personal communication) provide a fast and inexpensive approach, which can be used by breeders, seed companies, and official laboratories to monitor purity seed quality in maize seed production.

As observed in Figure 5 for the field sample at $3 \%$ of contamination, a less intense band of 1,600 bp was found. This is common in RAPD occurring when concentrations of DNA are low, with a weak interaction between the primer and annealing site in the genome, resulting in a weak discrimination for that locus (Welch et al., 1991). This fragment cannot be used for discrimination among the $\mathrm{F}_{1} \mathrm{~s}$, in agreement with Hashizume et al.,1993, but it can be used for verification of $\mathrm{F}_{1}$-hybrid seed purity of commercial corn.

The double hybrid BRS 201 and their contaminants showed to be genetically very close, being very difficult to detect phenotypic changes. In this case, for a practical use, clear distinction of a true hybrid may require several paternalspecific and hybrid-specific markers as postulated by Rom et al., (1995). Nevertheless, Hashizume 


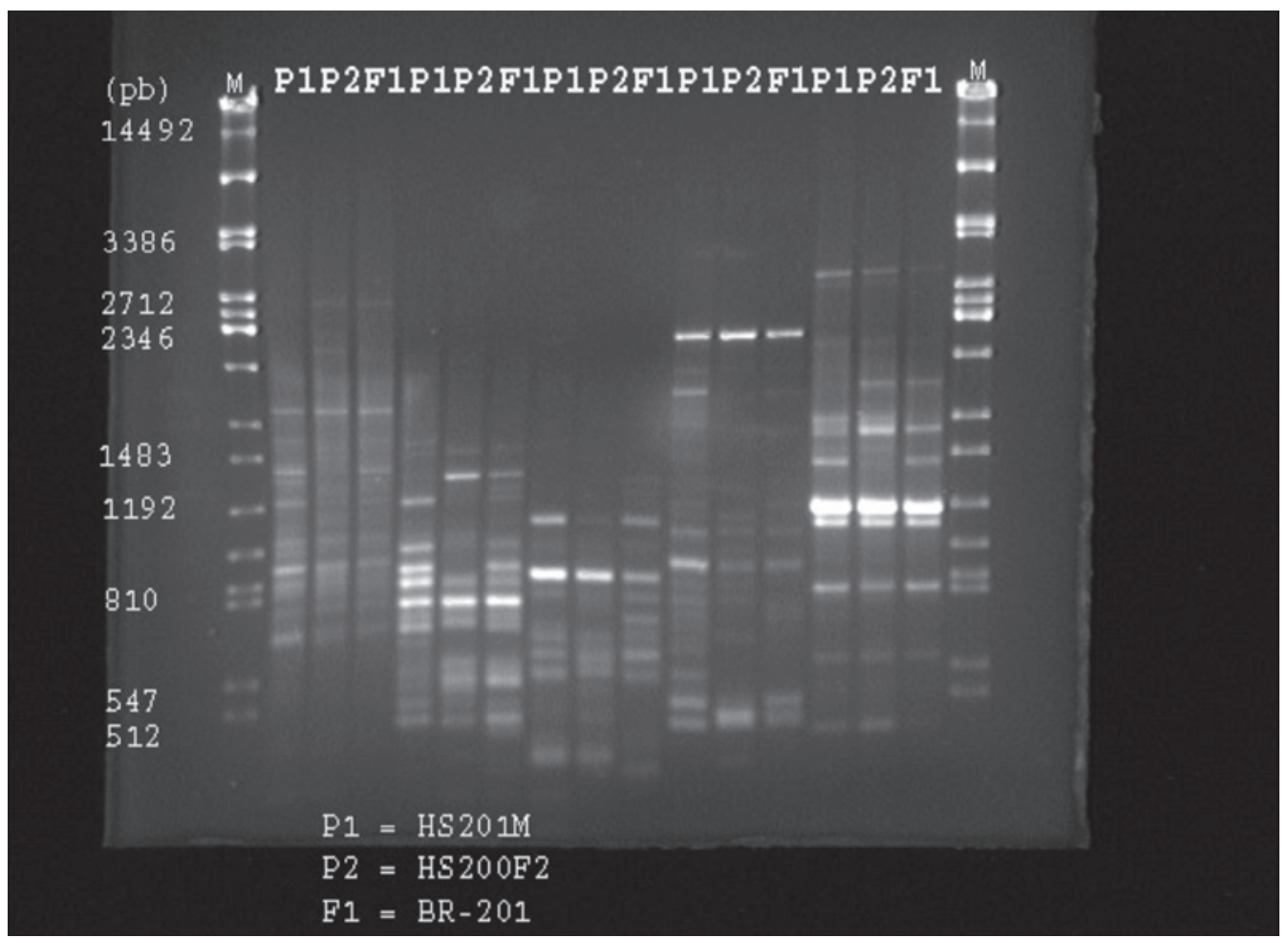

FIGURE 4. Agarose-gel electrophoresis of randomly amplified genomic DNA products from double hybrid BRS 201 and their corresponding single cross parents. The RAPD products shown were generated by the oligonucleotide primers, OPG-12, OPL-04, OPJ-16, OPO-09 and OPN-04. Lanes represent EcoRI, HindIII and BamHI digested 1-DNA size markers.

et al., (1993) reported the efficiency of RAPDs in the detection of genetic differences in watermelon lines (Citrullus lanatus L.) and tomato (Lycopersicon esculentum Mill), concluding that RAPD was appropriate for determination of genetic purity in hybrid seeds of these species. Also, Rom et al. (1995) observed the efficiency and feasibility of the RAPD technique for distinguishing differences between the parents and $\mathrm{F}_{1}$, mentioning that even a dominant genetic marker is useful in the varietal identification and control of genetic purity in seed lots of tomato hybrid.

An important aspect of this work was to demonstrate the efficiency of RAPD in distinguishing differences among levels of contaminants in inbred lines and corn double hybrid. Furthermore, this technique is also useful to the plant breeder and seed producer in the light of the Law of Plant Protection passed in 1997, which has been confirmed by Smith (1992) and Smith \& Helentjaris (1996) in the United States and Europe.

The use of RAPD markers has clear advantages over morphological traits because of speed and independence from environmental effects. Another great advantage is that contaminants could be detected before harvesting (Andreoli et al., 1996). The DNA technique has a further advantage that many hybrids tests of purity can be carried out as soon as three weeks after pollination and prior to harvest. Thus, the 


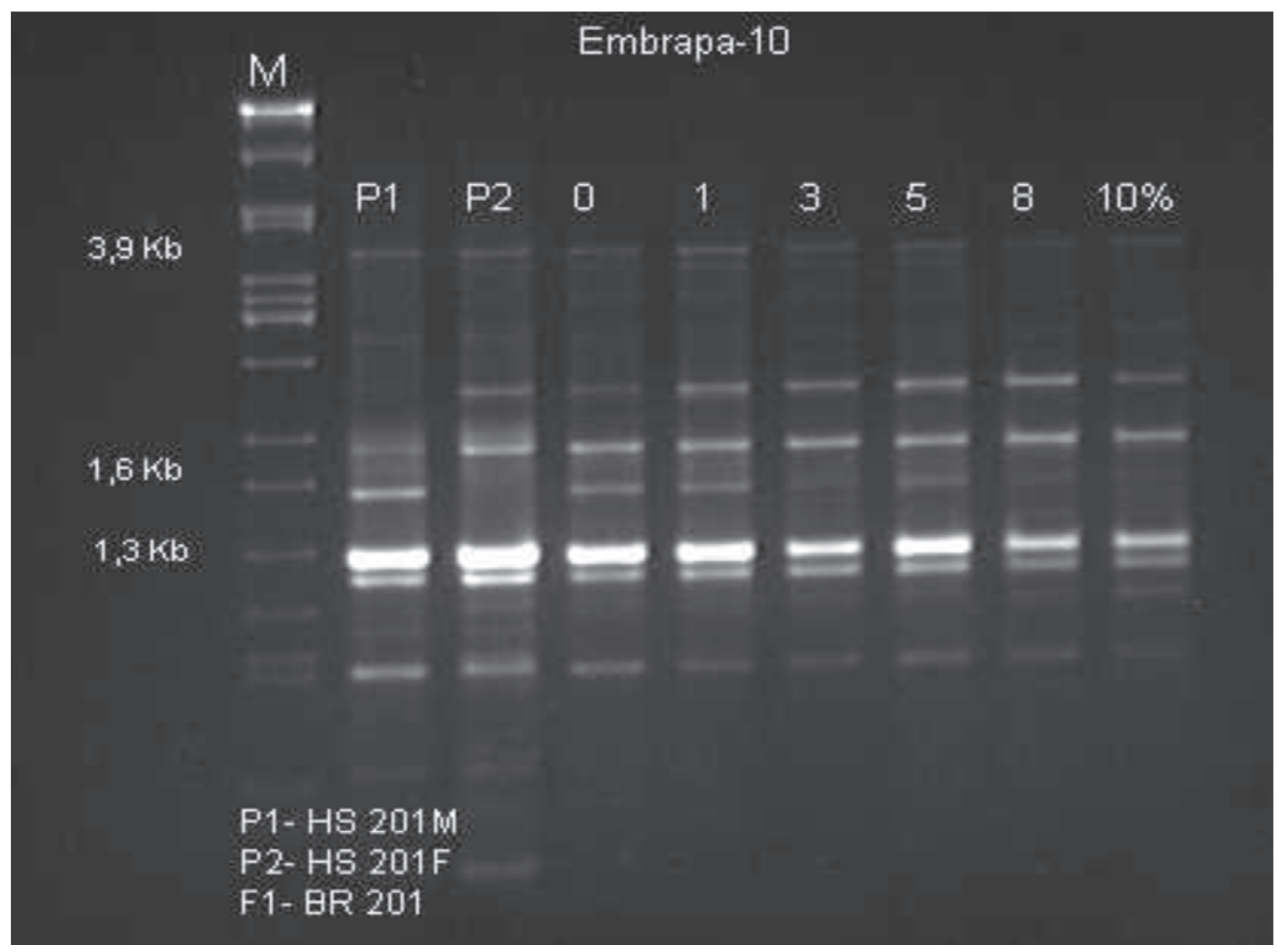

FIGURE 5. RAPD electrophoretic profile of corn using primer OPN-04. Fragments separated with $1,4 \%$ agarose gels in the P1 (HS male), P2 (HS female) and F1 (BRS 201 with its contamination levels of 0, 1, 3, 5, 8 and 10\% from field trial). Lane M represents 1-DNA markers digested with enzymes EcoRI, HindIII and BamHI.

time and cost involved in performing phenotype tests can be saved. With such results at hand, areas of suspected contamination within a seed field can be avoided at harvest as pointed out by Smith \& Wich (1986) using electrophoretic isozymes.

\section{Conclusions}

Grain yield inbreeding depression increased as contaminant level increased from 0 to $10 \%$ and was greater for the hybrid BRS 201 .

The paternal-specific RAPD technique allowed distinguishing $F_{1}$ pure seeds from the female self parents up to $3 \%$ contamination level for all hybrids.

This work indicates the practical usefulness of RAPD markers in monitoring purity tests and inbreed lines identification of commercial maize hybrids. The advantage of the DNA approach included speed and the ability to determine the percentage of female selfs prior to harvest.

\section{Literature Cited}

ANDREOLI, C.; CARVALHO, C. C.; LOPES, M. A. Mistura genética na produção de sementes 
de milho. In: CONGRESSO NACIONAL DE MILHO E SORGO, 21., 1996, Londrina. Anais... Londrina: ABMS: IAPAR, 1996. p. 268.

CAETANO-ANOLLES, G.; BASSAM, B.J.; GRESSHOFF, P.M. DNA amplification fingerprint using very short arbitrary oligonucleotide primers. Biotechnology, New York, v. 9, p. 553-557, 1991.

DOYLE, J. J.; DOYLE, J. L. Isolation of plant DNA from fresh tissue. Focus, Gaithesburg, v. 12, p.13-15, 1990.

DUVICK, D. N. Genetic rates of gain in hybrid maize yields during 40 years. Maydica, Bergamo, v .22, p. 187-196, 1977.

DUVICK, D. N. Genetic contributions to advances in yield of U.S. maize. Maydica, Bergamo, v. 37, p. 69-79, 1992.

HASHIZUME T.; SATO, T.; HIRAI, M. Determination of genetic purity of hybrid seed in watermelon (Citrillus lanatus) and tomato (Lycopersicum esculentum) using random amplified DNA (RAPD). Japanese Journal of Breeding, Tokyo, v. 43, p. 367$375,1993$.

MEGHJI, M. R.; DUDLEY, J. N.; LAMBERT, R. J.; SPRAGUE, G .F. Inbreeding depression, inbred and hybrid grain yield and other traits of maize genotypes representing three eras. Crop Science, Madison, 1 v. 24, p. 545-554, 1984.

MOLL R.H. AND STUBER, C.W. Quantitative genetics empirical results relevant to plant breeding. Advances in Agronomy, New York, v. 26, p. 277-313, 1974.

PINHO, E. V. R. von; PINHO, E. G. von; CICERO, S. M. Efeito da contaminação genética em campos de produção de sementes sobre o comportamento de diferentes híbridos de milho (Zea mays L.). Revista Brasileira de Sementes, Brasília, DF, v. 18, p. 256-261, 1996.

ROM M.; BAR, M.; ROM, A.; PILOWSKY, A M.; GIDONI, D. Purity control of $\mathrm{F}_{1}$-hybrid tomato cultivars by RAPD markers. Plant Breeding, Berlin, l v. 114, p. 188-190, 1995.

SMITH, S.; WEISSINGER, H. Rapid monitoring of purity in seed lots of hybrid maize. Modifications of current technologies. Maize Genetics Co-operation Newsletter, Columbia, v. 58, p. 103-105, 1984.

SMITH, J.S.C.; WYCH, R.D. The identification of females selfs in hybrid maize: a comparison using electrophoresis and morphology. Seed Science and Technology, Zurich, v. 14, p. 1-8, 1986.

SMITH, J. S. C. 1 Plant Breeders ' Rights in the USA; changing approaches and appropriate technologies in support of germplasm enhancement. Plant Varieties and Seeds, Cambridge, v. 5, p. 183-189, 1992.

SMITH O. S.; SMITH, J. S. C. Measurement of genetic diversity among maize hybrids: a comparison of isozymic, RFLP, pedigree and heterosis data. Maydica, Bergamo, v. 37, p. 5360, 1992.

SMITH, S.; HELENTJARIS, T. DNA fingerprinting and plant variety protection. In: PATERSON, A. H. (Ed.). Genome Mapping in Plants, New York: Academic Press, 1996. p. 95110.

TROYER A. F.; OPENSHAW, S. J.; KNITTLE, K. H. 1 Measurement of genetic diversity among popular commercial corn hybrids. Crop Science, Madison, v. 28, p. 481-485, 1988. 
WELSH, J.; MCCLELLAND, M. Fingerprinting genomes using PCR with arbitrary primers. Nucleic Acids Research, London, v. 18, p. 72137218, 1990.

WELSH, J. M.; HONEYCUTT, R.; MCCLELLAND, J; SOBRAL, B. W. S. Parentage determination in maize hybrids using the arbitrarily primed polymerase chain reaction
(AP-PCR). Theoretical and Applied Genetics, New York, v. 82, p. 473-474, 1991.

WILLIANS, M. N. V.; KUBELIK, A. R.; LIVAK, K. J.; RAFALSKI, J. A.; TINGLEY, S. V. DNA polymorphisms amplified by arbitrary primers are useful as genetic markers. Nucleic Acids Research, London, v. 18, p. 16531-6535, 1990. 